\title{
'Diabetes' as described by Byzantine writers from the fourth to the ninth century AD: the Graeco-Roman influence
}

\author{
H. Christopoulou-Aletra $\cdot$ N. Papavramidou
}

Published online: 26 March 2008

(C) Springer-Verlag 2008

\begin{abstract}
Diabetes was first extensively described by Aretaeus of Cappadocia, and his contemporary, Galen of Pergamum, in the second century AD. Aretaeus is said to have introduced the term diabetes, though there are some indications of previous references to the term. When referring to the disease, Galen accepts that the term belongs to 'other writers'. There are, in fact, many other Graeco-Roman accounts of diabetes, and in this paper we also examine the texts of Pliny the Elder (first century AD), Rufus of Ephesos (early second century AD), Oribasius (fourth century AD), Stephanus Alexandrinus (fifth century AD), Aetius (sixth century AD), Alexander of Tralles (sixth century $\mathrm{AD}$ ), and Theophilus Protospatharius (seventh century AD), together with his contemporaries Paulus of Aegina, Stephanus of Athens and Leon of Pella (ninth century $\mathrm{AD}$ ). All these writers use almost the same terminology when referring to the disease, and consider that symptoms of excessive thirst and urination are due to disease of the kidneys and the bladder. Similar treatments are also advocated, and relate to nutritional advice, herbal medications, poultices, bloodletting and abstinence from diuretic substances. Although there are no notable differences between the writings of Byzantine physicians and the earlier descriptions attributed to Aretaeus and Galen, this literature testifies to the fact that these physicians were well aware of a disease that Galen considered rare.
\end{abstract}

Keywords Aetiology · Byzantine writers · Diabetes . Greco-Roman writers $\cdot$ Symptoms $\cdot$ Treatment

H. Christopoulou-Aletra $(\bowtie) \cdot$ N. Papavramidou

History of Medicine, School of Medicine,

Aristotle University of Thessaloniki,

73 Nikis Ave.,

54622 Thessaloniki, Greece

e-mail: ealetra@med.auth.gr

\section{Introduction}

Ideas concerning diabetes in the early and mid-Byzantine times, from the fourth century to the ninth century AD, were largely derived from earlier writers, primarily Pliny the Elder, Galen of Pergamum and Aretaeus of Cappadocia. Roman medicine developed when Greek physicians came to practice medicine in Rome during the first century BC. Constantine the Great moved the capital of the Roman Empire from Rome to the city of Byzantium (later named Constantinople) in the fourth century $\mathrm{AD}$, and religious tolerance gave free rein to the practice of medicine in the newly formed Byzantine Empire. Byzantine medicine was based on one of the main principles of the new Christian religion, namely, philanthropy, and the Byzantine hospitals were founded in the monasteries. These hospitals received financial support from the Church, the government and private benefactors; they remained centres of scientific medical practice and education for 1,000 years [1]. Contemporary physicians studied medicine at the educational centres of antiquity, mainly Alexandria, but received further training from the chief physicians of their hospitals [2].

The professional medical writings of the time were compiled, preserving the medical knowledge of the past. These texts differed from pietistic Christian texts concerning charity, love, solidarity, devotion, sacrifice and miracles.

\section{Graeco-Roman medical ideas on diabetes}

Reference is made to polyuria, one of the major symptoms of diabetes, as early as $1500 \mathrm{BC}$ in the Papyrus of Ebers. Urinary urgency is mentioned by Apollonius of Memphis in the late third century BC [3]. During the Roman era, the presence of 'thin, white urine' is frequently mentioned, 
perhaps a manifestation of diabetes. However, when referred to by Pliny the Elder (4-79 AD) [4], it does not appear to be attributed to diabetes. Celsus, a contemporary, describes a condition of excessive urination and weight loss in the following terms [5]:

'But when the urine exceeds in quantity the fluid taken, even if it is passed without pain, it gives rise to wasting and danger of consumption; if it is thin, there is need for exercise and rubbing, particularly in the sun and before a fire. The bath should be taken but seldom, and the patient should not stay in it for long; the food should be astringent, the wine dry and undiluted, cold in summer, lukewarm in winter, and in quantity the minimum required to allay thirst. The bowels also are to be moved by an enema or by taking milk.'

The first detailed information concerning the aetiology, symptoms and treatment of diabetes derive from Rufus of Ephesus (98-117 AD), Aretaeus (120-200 AD) and Galen (128-200 AD). Caelius Aurelianus, a fifth century physician who translated Greek medical texts into Latin to transmit Greek medical views to Rome [6], mentions that Demetrius of Apamea, a Syrian-Greek colony in Phrygia [7], was the first to use the term diabetes, in the second century BC, but the writings of Demetrius have unfortunately been lost [8].

Rufus of Ephesus was a physician famous for his work on the variations of the pulse. He describes the symptoms of diabetes as 'incessant thirst' and immediate urination after drinking, which he calls 'urinary diarrhoea'. He advocates induced vomiting after drinking cold water and mixtures consisting of several substances, such as 'cyceon' and 'ptisane' and cooked vegetables. He states that substances that promote urination should be avoided. Steam baths are also advised to cool the head whilst heating the body. The treatment is similar to that advised for fever, detailed below [9]:

'We then, apply to the hypochondrium a poultice made of dust from alphitonia mixed with vinegar and oil from roses or with grinded tender leaves of vine or with cotyledon, with pellitory (parietaria Judaica), with purslane (pulli pes) or with any other similar substance. Before lunch, we frequently administer juice of bistort to drink, of helenion mixed in dark wine, or a maceration of dates, of the fruit of mirth or of pears. At the beginning, we also make a venesection to the elbow. Sometimes we have to use stupefying medicaments.'

Aretaeus describes diabetes as a dreadful, chronic disease that develops over a long period of time and is not common. Furthermore, according to his views, the aetiology of diabetes is based on humidity and coldness in the organism and on chronic diseases of the small intestine and the kidneys with 'hidden' malignancy. Its symptoms are described as follows [10]:

'The flow is incessant... the patient is short-lived... for the melting of the flesh is rapid, the death speedy. Life is disgusting and painful... Thirst, unquenchable; excessive drinking, which, however, is disproportionate to the large quantity of urine, for more urine is passed; one cannot stop them either from drinking or making water. Or if for a time they abstain from drinking, their mouth becomes parched and their body dry; the viscera seems as if scorched up; they are affected with nausea, restlessness and a burning thirst; and at no distant term they expire. Thirst, as if scorched up with fire... The abdomen shriveled, veins protuberant, general emaciation, when the quantity of urine and the thirst have already increased... the disease appears to me to have the name diabetes as if from the Greek word $\delta \iota \alpha \beta \eta \tau \eta \varsigma$ (which signifies a siphon), because the fluid does not remain in the body...'

Additionally, patients may suffer from decay or sudden death, or have a disgusting and painful life [10].

The treatment for diabetes is similar to that for dropsy [10]. Remedies are proposed to 'treat' the thirst originating from the stomach, such as purging the body with 'sacred' medicine (a mixture of many medicaments), compresses (made of spikenard, mastic, dates, raw quinces and rose oil), the sprinkling over the body of a mixture consisting of water boiled with fruits, styptic wine, shittah tree and hypocist, plus special food (milk with cereals, starch and wheat) [10].

Galen of Pergamum, the most celebrated Greek physician of the Graeco-Roman era (128-200 AD) refers to diabetes in several of his writings. He believed that diabetes was a rare disease in which the kidneys are affected. Regarding the naming of the disease, the frequency of its appearance and its symptoms, Galen writes [11]:

'Some people refer to chamber-pot dropsy, others again to diabetes or violent thirst... For my own part I have until now only twice seen a disease in which patients suffered from an inextinguishable thirst, which forced them to drink enormous quantities; the fluid was urinated swiftly with a urine resembling water ... diabetes is a genuine kidney disease analogous to voracious appetite.'

He noted some further symptoms that accompanied diabetes, such as vomiting after drinking, diarrhoea, retention of the content of the stomach, continuous desire for urination or dysuria $[12,13]$.

The aetiology of diabetes is attributed to malfunction of the 'retentive' faculties, as manifested by the continuous need for fluid and the inability of the kidneys to retain their content $[14,15]$. Probably as a result of limited experience 
with diabetes, Galen does not provide details of treatment. The writer of the pseudo-Galenic treatise De remediis parabilibus does, however, advise the patient to take very thin membranes from the abdomen of young roosters, dry them under the sun and eat them. If this cannot be done, he suggests that the patient should grind together mountain copper, dry acorn, flower of the wild pomegranate and oak gall, add to honey of roses and cold water, and drink the resulting mixture [14].

\section{Byzantine writers}

The physician Oribasius was a contemporary of the Emperor Justinian (320-400 AD) and was the first to collate a medical encyclopaedia by gathering all known medical texts of his time and arranging them thematically. His Synopsis has since been emulated by many other physicians [16]. Oribasius quotes Galen's and Rufus' writings on diabetes with respect to both the disease and its treatment: he considers diabetes to be a disease of the kidneys, and focuses on the inability of the organs to retain urine. He points out that some writers refer to it as 'chamber-

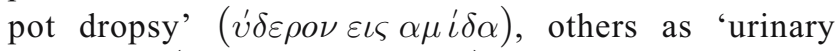
diarrhoea' ( $\varepsilon \iota \varsigma$ ov $\rho \alpha \delta \iota \alpha \rho \rho \circ \iota \alpha)$, 'diabetes' or 'extreme

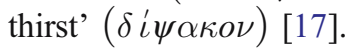

Stephanus of Alexandria was an Alexandrian physician of the fifth century AD who wrote on several subjects concerning the world, the sun, the 'sacred' art of making gold and the Hippocratic and Galenic treatises [18]. He dedicates only five lines to diabetes [19], which he describes as 'the excessive excretion of very thin and white urine.' He also says, 'The wisest men call it urinary diarrhoea, others extreme thirst... caused by the bad temperament of the kidneys.'

Aetius of Amida (527-565 AD), the first Greek physician to become a Christian, studied medicine in Alexandria and became the chief physician in the court of Emperor Justinian [20]. In his encyclopaedia, Aetius adopts the theories of Galen and provides further information from Aretaeus on the disease. He mentions the terms 'diabetes', 'chamber-pot dropsy' ( $v \delta \varepsilon \rho o \nu \varepsilon \iota \varsigma \alpha \mu i \delta \alpha)$, 'liuria'

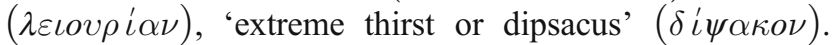
He advises medicaments like barley water with vinegar and roses, blood letting, poultices applied to the abdomen with vine leaves, navelwort, purslane and endive, raw eggs and the finest wheaten flour. He further advises pork and red wine [21].

Alexander of Tralles (525-605 AD) is considered one of the most renowned physicians and pharmacologists of the Byzantine era. His brother, Anthemios, was the architect of the church of St Sofia. Alexander wrote a medical encyclopedia in 12 volumes, encompassing topics ranging from internal medicine to surgery, ophthalmology, otolaryngology, gynaecology and pharmacology [18]. Alexander dedicates a detailed paragraph to diabetes, which considers the nomenclature, definition, aetiology, clinical manifestations and treatment of the disease. The terms that Alexander uses are 'diabetes', 'urinary diarrhoea' and 'dipsacus'. The proposed treatment aims to cool the body and restore hydration, since it loses its humidity from the incessant urination. Remedies include rhodomel, hydromel, rockfish, groats of wheat flour, rosatum, golden Attic wine, and raw vegetables such as lettuce or endive. Sweet foods and fruits were permitted, but patients were advised to avoid salted food, spices and dry fruits (e.g. peanuts, almonds) other than chestnuts [22].

In the seventh century AD the physician Theophilus was appointed both chief physician to Emperor Heraclitus and commander of the emperor's personal guard. From the latter came his name, Protospatharius, meaning the person who holds the first sword. According to Theophilus, the basic organs involved with the proper function of the human body are the brain, the heart and the liver. Theophilus wrote, among others, the synopsis On the Structure of the Human Body, based on previous writers' work, which included almost all known medical specialties of the time [18]. His reference to diabetes was based on Galen's texts, and he mentions that 'thin, white excessive excretion of urine indicates diabetes and that the wise men among the doctors named it chamber-pot dropsy (and the most eminent among them urinary diarrhoea) others extreme thirst' [23]. Paulus of Aegina (625-690 AD) also studied medicine in Alexandria. Medicine is his only preserved work, which consisted of 11 volumes [24]. He reported that diabetes 'is a rapid passage of the drink out of the body... and it is attended with immoderate thirst, hence called dipsacus, being occasioned by weakness of the retentive faculty of the kidneys... (it) deprives the whole body of its moisture by its immoderate heat' [25].

Paulus suggests the consumption of more dry food as a treatment. He also proposes that the following may be used: alica with rose wine, rhodomel, hydromel, some fresh wine, or some of the 'hot' wines, pot herbs, succory, endive or lettuces. With respect to fish, he recommends those that live among rocks. Other suggestions include eating the feet and womb of swine, pears, apples, pomegranates and cold water. Patients should drink 'propomata', i.e. medicines [26], 'from the juice of knotgrass and elecampane in darkcolored wine, and from the decoction of dates and myrtles'. Poultices made of polenta, vinegar and rose oil or of the leaves of the vine and navelwort, pellitory of the wall and purslain should be applied to the loins and abdomen. Paulus also recommends hot sweats, vomiting, cold water and avoidance of diuretics. Bloodletting is suggested at the onset of diabetes [25]. 
The writings of Stephanus of Athens, a student of Theophilus Protospatharious, provide commentaries on previous writers such as Hippocrates, Galen, Dioscorides and Theophilus [27]. Two such treatises are preserved. Diabetes is categorised among the disorders of 'conflicting nature', and is considered at the same time to be in a category including symptoms concerning the bodily excretions and those that are contrary to dysuria [27].

Leo the Philosopher, born in Pella, was a professor at the University of Magnavra in Constantinople and the archbishop of Thessaloniki. As was customary, Leo wrote his encyclopaedia; however, he also wrote about original works with comments as to whether he agreed or disagreed with the opinions and remedies described [18]. A very short paragraph is dedicated to diabetes, quoting from previous writers [28]: 'Diabetes is when people urinate incessantly as soon as they drink.' Leo mentions the names 'urinary diarrhoea', 'chamber-pot dropsy' and 'dipsacus' for describing diabetes. According to him, the cause of diabetes is the heat of the kidneys, which attracts the content of the stomach, thus provoking extreme thirst. He suggests that cold poultices made from roses and bramble should be applied to the abdomen.

\section{Discussion}

It may seem strange that diabetes is not described in the Hippocratic corpus, considering the multitude of accurate medical observations made its writers. Greek classical culture did, however, greatly value the external appearance of the human body, with an emphasis on slimness. Hippocratic regimens repeatedly refer to lifestyle interventions such as dietary management and exhaustive exercise [29]. Almost all pieces of sculpture and other artistic representations of the time depict the harmony of the slim human body. Roman views, however, especially those concerning dietary habits, are not in favour of a slim body [30]. This may explain why symptoms related to high food intake and laziness start to appear in the medical literature.

Roman and Byzantine physicians rarely refer to the Hippocratic 'humoral' theory in their explanation of the pathogenesis of the disease, even though dehydration was considered an important therapeutic aim, to prevent incessant urination. For this reason, both vomiting and abstinence from fluids is advocated. Galen's theories do, however, permeate and influence the Byzantine texts. Numerous works of later Greco-Roman and Byzantine authors follow Galen and Aretaeus more or less to the letter, and use the term diabetes among other descriptive expressions. Thus, diabetes was apparently as well recognised in the Greco-Roman era as it was during Byzantine times. Physicians of the time produced some original works, but mainly relied on copying, collecting and reproducing texts in encyclopaedias or synopses. This ensured preservation of the knowledge of the past and its transmission to subsequent generations.

Christian philanthropy influenced the founding and organisation of the Byzantine hospitals, which were otherwise run with a scientific and administrative system resembling that of modern hospitals. Dogmatism and prejudices were left aside. These physicians were not charlatans but scientists educated at the best educational centres of their time, who were later appointed to high positions. Their works were, by chance, preserved and copied in the monasteries of the Eastern as well as the Western territories. Some were translated into Arabic and were reintroduced - after the conquests by the Arabs of the Mediterranean territories - back into Western civilization. The only dogmatism evident among educated physicians, but still based on rationalism, related to Galenic medicine, or Galenism. The Christian Church imposed this orthodoxy until almost the end of the Renaissance.

For most writers, diabetes was considered to result from kidney malfunction and the consequent inability to retain urine; the consequences were causes extreme urination and incessant thirst. Humidity and coldness in the body and 'hidden' malignancy in chronic diseases of both the small intestine and the kidneys were additional causes of diabetes. Aretaeus is unsure of the origin of the name diabetes, which evidently preceded his times: 'it appears to me to have got the name diabetes from the Greek word $\delta \iota \alpha \beta \eta$ i $\tau \eta \varsigma^{\prime}[10]$. Galen's words also make it clear that he did not introduce the term diabetes. Aretaeus and Galen consider diabetes both as a disease and as a symptom analogous to voracious appetite. Another point is that neither the Roman nor the Byzantine writers mention the sweet taste of the urine.

The disease was considered to affect the elderly, since it develops over a long period of time, and most writers agreed that diabetes is lethal. Therapies resemble those for fever and dropsy, and revolve around dietary management and special beverages, poultices, steam baths, blood letting, promotion of sweats and vomiting, abstinence from diuretic substances, and - perhaps in the terminal stages - stupefying substances.

\section{Epilogue}

Diabetes was certainly not neglected by the Graeco-Roman and Byzantine writers. The earliest written report may have been written in the second century $\mathrm{BC}$, but is not preserved. The first full reports are those Rufus, Galen and Aretaeus in the second century $\mathrm{AD}$, and these in turn influenced the Byzantine physicians. The descriptions of the symptoms are consistent, but the proposed treatments were only aimed at 
alleviating symptoms by limiting excessive urination. The term 'urinary diarrhoea' is transmitted from Rufus' writings to subsequent writers. Oribasius quotes directly from Rufus and Galen, while Paulus of Aegina quotes from Oribasius. Theophilus and Aetius copy from Galen, and the term 'diabetes' is present in all Byzantine writers' treatises, along with 'uinary diarrhoea' and 'extreme thirst'. The production of thin, white urine is usually mentioned. The Byzantine physicians were evidently familiar with diabetes but had little to add to the ideas introduced by Rufus, Galen and Aretaeus.

\section{References}

1. Miller TS (1997) The birth of the hospital in the Byzantine Empire. Johns Hopkins University Press, London, pp XI-XXIX

2. Constantelos DJ (1991) Byzantine philanthropy and social welfare. Caratzas, New York, pp 129-135

3. Deanna RN, Swartout-Corbeil M (2006) Diabetes mellitus. Encyclopedia of nursing and allied health. Available from http:// www.findarticles.com/p/articles/mi_gGENH/is_/ai_2699003226, accessed 15 February 2008

4. Pliny the Elder (1885) In: Bostock J (ed) The natural history. Taylor and Francis, London Book 28

5. Celsus C (1971) De medicina. Book 4. Harvard University Press, Cambridge, $\mathrm{p} 451$

6. Kroh P (1996) Lexicon of ancient Greek and Latin writers. University Studio Press, Thessaloniki, p 512

7. Smith W (1867) Dictionary of Greek and Roman biography and mythology. Vol. 1. Little, Brown and Company, Boston, p 971

8. Spandagos V, Spandagou R, Travlou D (1996) Doctors and pharmacologists of ancient Greece. Aithra, Athens, pp 154-155

9. Rufus of Ephesus (1879) Traité des maladies des reins et de la vessie. In: Daremberg Ch (ed) Euvres de Rufus d'Ephèse. L'Imprimerie Nationale, Paris, p 35 (in French)

10. Aretaeus of Cappadocia (1997) On the causes and signs of chronic diseases. Book 2. Kaktos, Athens, pp 203-207

11. Henschen F (1969) On the term diabetes in the works of Aretaeus and Galen. Med Hist 13:190-192
12. Galen of Pergamum (1824) De symptomatum differentiis. In: Kuhn CG (ed) Claudii Galeni Opera omnia. Vol. 7. Libraria Car. Cnoblochii, Lipsiae, pp 81 (in ancient Greek)

13. Moraux P (1985) Anecdota Graeca minora vi: Pseudo-Galen, de signis ex urinis. Z Papyrol Epigr 60:68-74 (in ancient Greek and German)

14. Galen of Pergamum (1827) De remediis parabilibus. In: Kuhn CG (ed) Claudii Galeni Opera omnia. Vol. 14. Libraria Car. Cnoblochii, Lipsiae, pp 475 (in ancient Greek)

15. Galen of Pergamum (1824) De locis affectis. In Kuhn CG (ed) Claudii Galeni Opera omnia. Vol. 8, Book 6. Libraria Car. Cnoblochii, Lipsiae, pp 400 (in ancient Greek)

16. Cumstom CG (1996) The history of medicine from the time of the Pharaohs to the end of the XVIIIth century. Routledge, New York, p 239

17. Oribasius (1873) About diabetes. From Galen. In: Daremberg, Bussemaker (eds) Synopsis. Book 9. L'Imprimerie Nationale, Paris, pp 520

18. Georgakopoulos K (1998) Ancient Greek Physicians. Iaso, Athens, pp 34-5, 220-1, 312, 419-420 (in Greek)

19. Bussemaker UC (1845) In Magni sophistae librum de urinis. Revue de Philologie 1:423-438 (in ancient Greek and French)

20. Marketos S (2000) History of Medicine. Zitros, Athens, p 139 (in Greek)

21. Aetius of Amida (1874) On diabetes, from Galen. In: Daremberg C and Ruelle CÉ (eds) Oeuvres de Rufus d'Éphèse. Book XI. Imprimerie Nationale, Paris, pp 85-90 (in ancient Greek and French)

22. Alexander von Tralles (1879) Ueber den diabetes. In: Puschmann T (ed) Alexander von Tralles original-text und Übersetzung. Vol. 2. Braumuller, Vienna, pp 493 (in ancient Greek and German)

23. Ideler JL (1963) Physici et medici Graeci minores. Vol. 1. Hakkert, Amsterdam, pp 261-283 (in ancient Greek)

24. Castiglioni A (1961) History of medicine. Vol. 1. Minotauros, Athens, p 252 (in Greek)

25. Adams F (1844) The seven books of Paulus Aegineta. Vol. 1. Sydenham Society, London, pp 224-225, 547

26. Stamatakos I (1999) Lexicon of the Ancient Greek language. Vivliopromitheutiki, Athens (in Greek)

27. Dickson K (1998) Stephanus the philosopher and physician: commentary on Galen's Therapeutics to Glaucon. Brill, Leiden, p 243

28. Ermerins FZ (1963) Anecdota medica Graeca. Hakkert, Amsterdam, pp 80-86, 89-217

29. Christopoulou-Aletra H (2001) The significance of body weight in the "Hippocratic Corpus". Türkiye Klinikleri Journal of History of Medicine 1:30-33

30. Alföldy G (1988) History of the Roman society. Educational Foundation of the National Bank, Athens, p 168 